\title{
LEVINAS AND THE SYMBOL OF THE TEMPLE OF JERUSALEM FOR THE WHOLE OF HUMANITY
}

\section{LEVINAS Y EL TEMPLO DE JERUSALÉN COMO SÍMBO- LO PARA TODA LA HUMANIDAD}

\author{
Juan J. Padial ${ }^{1}$ \\ Universidad de Málaga (España)
}

\begin{abstract}
Levinas does not speak quite often about the Temple, but in his Talmudic commentaries, he says quite impressive things about the Temple and its image. Commenting the Tractate Yoma 10a of Talmud, he says that «The Temple of Jerusalem in Jewish thought is a symbol, which signifies for the whole of humanity». This paper focuses on clarify this sentence and the universality of one Temple, which «is an exact replica of the heavenly Temple, the order of absolute holiness» according with his comment to Rabbi Hayyim Volozhiner. I research the symbolic value of the Temple in Jerusalem built as in ruins and try to connect this value with the rest of Levinas' philosophy, especially with his theory of sacrifice as substitution.
\end{abstract}

Palabras clave: Temple of Jerusalem; Politics-Messianism; History; Responsibility; Guilt; Holiness; SaCrifice.

Resumen: Levinas no suele hablar del Templo, pero en sus comentarios talmúdicos, dice algunas cosas muy impresionantes acerca del templo y de su imagen. Así, al comentar el Tratado Yoma 10a del Talmud, dice que «El templo de Jerusalén, según el pensamiento judío, es un símbolo, que significa para la humanidad entera». Este artículo se centra en clarificar esta tesis de Levinas y en la universalidad de un sólo templo, que según su comentario al Rabbi Hayyin Volozhiner «es una réplica exacta del Templo celestial, el orden de la santidad absoluta». Investigo el valor simbólico del templo de Jerusalén, tanto construido como en ruinas, e intento conectar este valor con el resto de la filosofía de Levinas, espcialmente con su teoría del sacrificio como substitución.

Key Words: Templo de Jerusalén; Mesianismo político; Historia; ReSPONSABIlidad; CUlPa; SANTIDAD; SACRIfICIO.

[1] is professor of philosophy at the University of Málaga. His research interests are philosophical anthropology and German idealism. His email is jjpadial@uma.es 


\section{The symbolic value of the Temple of Jerusalem: some dif- ficulties}

In Beyond the Verse. A set of Talmudic Readings and Lectures, the Jewish ${ }^{2}$ philosopher Emmanuel Levinas does not speak frequently neither about temples, nor the Temple in general. However, in the few passages where he speaks of it, he says quite impressive things. The first of them is that

«The Temple of Jerusalem in Jewish thought is a symbol which signifies for the whole of humanity; it is not simply a national institution». ${ }^{3}$

According to this thesis, the Temple of Jerusalem differentiates itself of other temples. Perhaps the most immediate example should be Mount Gerizim, the central spatial point of Samaritan religion. Most of its believers live around this mount, where they worship God and perform their rituals — sacrificing, celebrating the Passover, etc.-. Believing in the sanctity of Mount Gerizim is the same thing as being a Samaritan, and for that reason, Mount Gerizim is a national institution and not a symbol of mankind.

The Quran, on the contrary, makes of the Kaaba the temple for the whole of humanity. As It says in the verse 96 of the third Surah:

«Verily, the first House (of worship) appointed for mankind was that at Bakkah (Makkah), full of blessing, and a guidance for mankind». ${ }^{4}$

Mecca due to the religious significance of the Kaaba, is a completely and utterly holy place for Islam. But the symbolic value both of Mecca

[2] David Patterson characterizes Levinas as a Jewish thinker. As he holds «a philosopher's thinking is Jewish, inasmuch as it is deeply informed by the Hebrew language, Jewish sacred texts, the teachings of Torah and Talmud, a concept of divine creation, and related notions». The Talmudic texts are not only a matter of interpretation, but a point of departure for Levinas' philosophy. This tradition is a set of conscious assumptions on the base of Levinas' thinking. This paper focuses mainly on the widespread repercussions of Jewish tradition of Levinas thinking about the Other. Patterson's quote can be found in: Patterson, D., "What makes Emmanuel Levinas a Jewish Thinker» in Serpytyte, R., A Century with Levinas. On the Ruins of Totality, Vilnius University Publishing House, Vilnius, 2009, p. 17. As Levinas himself confesses in 1975 "philosophy is derived from religion. It is called into being by a religion adrift, and probably religion is always adrift». Levinas, E. "Damages Due to Fire», in Nine Talmudic Readings, trans. Annette Aronowicz, Indiana University Press, Bloomingtonm 1990, p. 182.

[3] Levinas, E., Beyond the Verse. Talmudic Readings and Lectures, Indiana University Press, Bloomington, 1994, p. 63.

[4] The Holy Quran: Text, Translation and Commentary, 3:96. Translated by Yusuf Ali 
and Kaaba are different from the one of Jerusalem and its Temple. According to Levinas and Jewish tradition, the Temple of Jerusalem signifies for the whole of humanity, whereas Jerusalem is a holy city for Judaism, Islam, Christianity and even Mandaeism. The Kaaba, according to Islamic religion, was the first Temple addressed by God to mankind and blessed by Him. It is a sacred and blessed temple for all nations on Earth - <ālaminn-, because of Hagar and Ishmael who are said to be buried there. They two belong to Yahweh's promise to Abraham, and as the Qur'an puts in the mouth of Abraham:

«O our Lord! I have made some of my offspring to dwell in a valley without cultivation by thy Sacred House; in order O our Lord that they may establish regular prayer: so fill the hearts of some among men with love towards them and feed them with Fruits: so that they may give thanks». ${ }^{5}$

Abraham, sending into exile Hagar and Ishmael (some of his offspring) into the wilderness of Beer-sheba (the valley without cultivation in the Desert of Paran), sets up a sacred place for ishmaelites. An isolated place in the wilderness for regular prayer and praise, that is: a cloister forever, where the ishmaelites can spiritually uplift. However, Mecca does not signify for the whole of humanity, but for some of the descendants of the Promise to Abraham.

It seems to be, that temples are cultural institutions. Why, then, the Jewish thought, and Levinas with it, holds that the Temple in Jerusalem can signify for the whole of humanity? Which arguments support it?

Firstly, we must warn a misunderstanding. To associate the Temple of Jerusalem with humanity appears to indicate a sacralization of humanity. Comte thought in that way: one must serve humanity. The ethical demand of the religion of humanity says: Vivre pour autrui! ${ }^{6}$ One must live for others! One must be a servant of humanity, and not a slave of God. However Judaism is not a religion of humanity. For Levinas, Humanity cannot be associated with God, and Judaism is a religion of the revelation of God to Humanity, of Its Torah.

Nevertheless, in the Jewish philosophical area Jacques Derrida and Daniel Breslauer support the view of a "Judaism without Religion», ${ }^{7}$ an inclusive Judaism that embraces all form of the other that it had pre-

[5] Ibid., 14:37.

[6] Comte, A., Système de politique positive, ou, Traité de sociologie, instituant la religion de l'humanit, République Occidentale, Tome Deuxième, 1852, p. 371.

[7] Cf:: Breslauer, D., Creating A Judaism Without Religion: A Postmodern Jewish Possibility, University Press of America, Lanham, 2001. 
viously excluded, a secularized Judaism in which, one can find "Yiddish interrupting Hebrew, Hasidism interrupting rabbinism, women interrupting the masculinism of Jewish culture, and gays interrupting Israeli heterosexism». ${ }^{8}$ However it is obvious that Levinas finds itself pretty far from the ideas both of the secular humanists, and of the liberal Jews. Levinas does not put in the center of human existence humanity, but the Other. Not the self, neither the same, but the other of the same. And this entails that Levinas rejects the idea of liberal Jews of reducing the Other to the same of humanity. In which sense, then, Levinas thought a temple of such great importance, like the one of Jerusalem, as symbolizing the whole of humanity?

\section{The text: Levinas as a Talmudic reader and interpreter}

The text about the symbolic value of the temple in Jerusalem is extracted from a chapter in which Levinas comments the Talmudic Tractate Yoma 10a, that speaks about the Romans, the Persians, and the Chaldeans, about wars and about political decisions. Both Chaldeans and Romans destroyed the Temple of Jerusalem. Levinas focuses both on the «builders or destroyers of the Temple» ${ }^{9}$. However, the symbolic value of the temple in Jerusalem remains unaltered. Both in the rituals performed in the Temple so long as it was built, and in the remaining ruins of the Temple, it always signifies for the whole of humanity. But it signifies it in different ways, as we shall see.

According to him, the social and political power of other cultures and peoples is judged in reference of their actions regarding the Temple, that is, with respect to humanity, which is symbolized in this ethical and religious institution of Israel. So, the Temple of Jerusalem is not only a national institution, but the symbol of (i.) an ethical demand to all other peoples and nations, and (ii.) of the answer of these other people to that demand.

From the time of Romans, the Temple does not exist anymore. A political power destroyed it after the long history of its early building, and its successive devastations and restorations. It seems to be an empty place, only ruins, but ruins of the place of revelation of God to Abraham and Isaac. Consequently, these ruins are speaking to humankind not only about the rituals performed centuries ago in them by the people of Israel,

[8] Martin Kavka review of Daniel Breslauer's Creating a Judaism without Religion, in Shofar: An Interdisciplinary Journal of Jewish Studies, 22-2/2004, p. 175.

[9] Levinas, E., Beyond the Verse. Talmudic Readings and Lectures..., p. 63. 
but about the Ark of the Covenant which was deposited inside it, and of the relationship of men with the sacred ethical demand expressed in the Ten Commandments, which were the revelation of God to Moses. For that reason, these ruins are a good symbol of a relationship of «a humanity of the Torah ${ }^{10}$ with God that cannot be inserted in a totality with the political history. Holy history and universal history does not form any totality.

The relationship between God and humanity is one of the main themes of Levinas' philosophical thinking. A theme which came to him by his Jewish tradition. The Temple can be thought as the space where that relationship is accomplished. As such, the Temple can be thought as the space where transcendence is manifest. This is Heidegger's approach. For him, the temple is related to the presence of the god.

«This presence of the god is in itself the extension and delimitation of the precinct as a holy precinct. The temple and its precinct, however, do not fade away into the indefinite. It is the temple-work that first fits together and at the same time gathers around itself the unity of those paths and relations in which birth and death, disaster and blessing, victory and disgrace, endurance and decline acquire the shape of destiny for human being». ${ }^{11}$

For Heidegger, the temple is a symbol, which signifies for the world that it unconceals; the world which gathers around it. The temple is the symbol of $a$ culture, of a world-view that "gives to things their look and to men their outlook on themselves». ${ }^{12}$ For Heidegger the Temple is firstly a work of art. And as such, its main function is to establish a world, the unconcealment of a congruent set of meanings of the Being. But Levinas speaks neither of the Temple in general, nor of a Greek temple, but of a particular, and non-Greek temple: the Temple in Jerusalem. As García explains, Levinas disagrees with Heidegger, because «the human being as being-in-the-world is not the human being open to any other human beings in a passive and receptive wayn. ${ }^{13}$ For Levinas, this Temple does not speak only about Jewish culture, Jewish institutions or Jewish world, but about humanity, the whole of humanity.

And the Temple of Jerusalem signifies for the whole of humanity even in its absence. For Heidegger, the presence of the holy prescient

[10] Ibid., p. 52.

[11] Heidegger, M., «The Origin of the Work of Art» in Poetry, Language, Thought, Translated by Albert Hofstadter, Harper \& Row, 1971, pp. 40-1.

[12] Ibid., p. 42.

[13] García, J. A., Introducción a la filosofía de Levinas, Cuadernos de Anuario Filosófico, Serie universitaria, $n^{\circ}$ 140, Pamplona, 2001, p. 32. 
unconceals a whole world. For Levinas, it is the absence of the Temple, which is symbolic. Against Heidegger, who speaks about Being, Levinas is thinking about nonbeing. ${ }^{14}$ As Ira F. Stone explains "the destruction of the Temple poses a problem: how to provide a hope for redemption in its absence; but it is not necessarily an irresoluble problem», ${ }^{15}$ because if the Jewish tradition sees "the holy as a who, and not as a what», ${ }^{16}$ then one can say that a Temple in ruins shows better the holiness than the Temple perfectly constructe, because for a thing to be in ruins means the vanishing of his character of a what. Moreover, for Levinas, the other is beyond any possible presence, and for that reason, it cannot be present. It is beyond any subject's experience, outside consciousness, and for that reason it has a negative transcendence. It is the same absence of the Temple, which speaks to us.

The Temple is not anymore, a totality, but a place of fragments which speaks to us about war, suffering, deportation, invasion, and conquest, that is, these ruins speaks to us about the violence inflicted to the ethical and religious demand. For that reason, the ruins of the Temple of Jerusalem appeal to our responsibility. They are an appeal directed to the core of our subjectivity, which is defined by the fact of having ethical duties, moral obligations, with the Other.

\section{Political Theology and the problem of Messianism}

However, the ruins of the Temple of Jerusalem speak to us about the relationship of politics with holy History, too. «This latter does not immediately triumph over universal History, which inexorably unfurls; but it does allow it to be judged». ${ }^{17}$ For that reason the Temple of Jerusalem is not a symbol of the messianic peace, but of the primacy of ethical demands over political and juridical powers. The ruins of the Temple are a symbol of the priority of ethics for all other people of the Earth.

According to Levinas, Yoma 10b is a Talmudic text, in which some rabbinical scholars discuss a prophecy about the end of history. It is a

[14] Cf:: Kavka, M., Being and nonbeing: The appropriation of the Greek concept of to me on in Jewish thought, Rice University, Houston, 2000.

[15] Stone, I. F., Reading Levinas/Reading Talmud: An Introduction, The Jewish Publication Society, Philadelphia-Jerusalem, 1998, p. 92.

[16] Patterson, D., «What makes Emmanuel Levinas a Jewish Thinker»..., p, 17.

[17] Levinas, E., Beyond the Verse. Talmudic Readings and Lectures...., p. 52. 
prophecy that predicts a war between the Persians and the Romans, that is, between two great empires.

«It concerns the possible war which should end History and which would be played out —if wars are played out— between these two empires». ${ }^{18}$

History, for Levinas, is the human time in which one can achieve individual or collective goals. These goals are understood as the real ends of History, and for that reason history has a meaning. But to develop these goals and to conclude history, it is needed the work of politicians. History consequently is the time for politics, for ambitions, for the construction of a social order, and for a permanent establishment for the final aim of history. The flow of time in history is directed towards future, towards an end, a goal.

This vision of history is a Kantian or Hegelian one: history has an end, and a moral end. It is a development, for instance, of freedom or self-consciousness, or the construction of a reign of ends. And it means it cannot be only violence, but persuasion, science, bureaucracy, etc., too. Politics is the place of rivalry, not necessarily war. But politics always suggest an idea of a struggle towards ends, an idea "on the meaning of political life which, admittedly, is not always war, and which can become rivalry, competition and even pure emulation, during periods of peaceful coexistence between powers». ${ }^{19}$ A clash of civilizations, or a war, means always at least two different and incompatible goals. In any case, politics means always the reduction of the other to the same, to the universal for which the politician is fighting. Consequently, politics is an egology, an act of reduction of the other to the totality of the same.

However, developing the principle of history towards its conclusion, to establish the reign of ends, or to extend freedom to all humanity, is for Levinas tantamount to "the false Messianisms of modern times (times, however, which are defined as times of conclusions». ${ }^{20}$ Politicians and philosophers of history, which proclaim an end and a meaning to history,

[18] Ibid., p. 54.

[19] Ibidem.

[20] Ibid., p. 17. These "false Messianisms of modern times» has been the object of research of Terence Holden in Levinas, Messianism and Parody, Continuum, London and New York, 2011. I think that Holden does not bear in mind that Levinas speaks of «false Messianism». This adjective implies that for Levinas there is a true and a false Messianism. Perhaps modern philosophical history and political theology can only be considered as parodies of Messianism. But as parodies they distort the truth of Messianism. As Martin Kavka has shown one can find in Levinas a «demythologizing the concept of the Messiah». Kavka, Martin, Jewish Messianism and the History of Philosophy. Cambridge University Press, New York, 2004, p. 197. 
are then false Messiahs, because to point a goal in a possible future that gives meaning to all the rest of the time "relativizes and devalues every moment [...] foreseeing a supra-temporal eternity of ideal». ${ }^{21}$ We can find some examples of false Messianism in the leibnizian theory of indefinite progress, the development of history in Hegel, the historical progression of Marxism to the communist State, or the Law of three stages formulated by Comte. All false Messianisms have in common the certainty in a future and secular completion and salvation of humanity. Salvation of exploitation, of slavery, of suffering. False Messianism then, anticipates an optimist future for the whole of humanity. One can remember here that Comte venerated humanity and called it «le grand être», the great being. False Messianism are secular prophecies. According to Levinas, history contrasts with true Messianism and eschatology. True Messianism has nothing to do with fighting for a goal, with historicism, or with a devaluation of the present or past time. Eschatology has nothing to do with goals, achievements or history.

There is a large tradition of Jewish philosophers offering different interpretations of Messianism: Maimonides, Hermann Cohen, Franz Rosenzweig, Emile Fackenheim, Emmanuel Levinas, and Jacques Derrida. Most of them have confronted with the historicism of the nineteenth century, and for that reason with the false Messianism of Political Philosophy and Theology. ${ }^{22}$ However, P. Gordon ${ }^{23}$ or Martin Kavka, among others, have shown that Levinas must be detached from these philosophers.

To bring Messianism up into the question of the symbolic value of the Temple is very important to Jewish eschatology, because the construction of the Third Temple (Beit haMikdash haShlishi) and the restoration of the sacrificial worship (Korban) will occur in the era of the Messiah. So, the meaning of the messianic time, the wish of undertaking the rebuilding of It, and to hope the resumption of the sacrificial cult, are matters of great significance for Judaism. An importance which is expressed in the prayer of the Amidah, on the core of the daily Jewish liturgy. But in this approach, Messianism and Temple are linked together to a particular religion and does not signify for the whole of humanity.

In Difficult Freedom, Levinas explains what he understands under «Messianism». Messianism is not related to history, or to the telos of

[21] Levinas, E., Beyond the Verse. Talmudic Readings and Lectures...., p. 54.

[22] Cf. David Myers's Resisting History. Historicism and Its Discontents in German-Jewish Thought, Princenton University Press, Princenton, 2010.

[23] Gordon, P. Rosenzweig and Heidegger. Between Judaism and German Philosophy, University of California Press, Berkeley, Los Angeles, London, 2003. 
history. If it were so, then the "Messiah" should not differentiate himself from a politician. A politician works for a better world in the future, and this entails a predictable future. Politicians must anticipate a totality in the future and work for it. But one of the key features of the Messiah is the unpredictability of his arrival. One cannot anticipate the messianic times. The Messiah lives in the time of the surprise. And to live in hope of the Messiah means to live hoping for the surprise, or the disturbance, of the Other. The temporality of true Messianism cannot be fully constituted by a subject thinking and projecting his actions from the first person, not by an impersonal process either. Against the foreseen totality, the other is infinite because it transcends any thought of the self. The appeal of the other cannot be anticipated, neither in its form nor its content. The subject cannot anticipate what the other can demand from oneself, nor the way in which he shall be appealed.

The first person does not have the priority. One must be open for the appeal of the other, a second person with which one encounters. Without intersubjective experiences the ethical demand is a mere empty formalism. And for that reason, the subject must empty out itself in order to be for the appeal, for the other. As Irina Poleshchuhk explains, «Messianic temporality comes as a disturbance of the present time of subjectivity -as inverted and displaced sensibility - deprived of making choices or carrying out moral actions, but at the same time gaining its future freedom by giving a gift of time in promising and asking for forgiveness. One of the advantages of this view is its ability to see the temporality of futurity as correcting itself in chains of intersubjective experiences and not as an isolated act of fulfilling expectation». ${ }^{24}$ Politics have, as an essential feature of its temporality, the anticipation, the foresight. In a political action one must foresee what is going to happen. And false messianisms are always pointing to a victory in a future. But one cannot foresee the appeal of the other. Moreover, one cannot ever predict the consequences of the own actions. For that reason, one must always be in disposition to ask for forgiveness, and to act in the interest of the other. The appeal of the other is always caused by his suffering. And for that reason, true Messianism has to do with my responsibility with any suffering of the other. Consequently, a destroyed temple, a temple, which has suffered violence against it and against the people, which congregates around it, can be a good symbol of our universal responsibility with any form of suffering.

[24] Poleshchuk, I., «The Ethics of Futurity: Messianism and Intersubjectivity» in International Journal of Humanities and Social Science Vol. 4, No. 5(1); March 2014, p. 66. 
"Messianism is therefore not the certainty of the coming of a man who stops History. It is my power to bear the suffering of all. It is the moment when I recognize this power and my universal responsibility». ${ }^{25}$

It is not casual that Levinas worked from 1930 in the Alliance israélite universelle. Although the motto of this organization is that «All Jews bear responsibility for one another», Levinas, as we shall see, following Dostoievski, broads this thesis to all humanity: "All human beings bear responsibility for one another». My responsibility is an infinite one because my wish cannot be reduced. The human wish and longing for infinite, is reduced by any form of false Messianism, by any anticipated totality. ${ }^{26}$

One can hear the echoes of this text in many others of Levinas. Messianism is confronted with politics through the question of suffering. Often politics is entrusted to «eradicating evil through war». ${ }^{27}$ A legitimate mission of politics, it is said, maybe to punish other peoples and nations, because the state is the "only human Gemeinschaft which lays claim to the monopoly on the legitimated use of physical force». ${ }^{28}$ For that reason, only politics through the State - Gewaltmonopol des Staates - can have as a task to combat against evil and suffering. But then we find here a clash of attitudes in front of suffering. The attitude of politics and the attitude of Messianism.

Politics has as an essential possibility the legitimation of inflicting suffering as a mean to achieve justice. As a result, a politically just act can entail a great dose of violence. And for this reason, it is needed Messianism and eschatology. Levinas finds this idea in the comment of Rabbi Johanan bar Nappaha to Jeremiah 30:6-7:

«That is not, then, what R. Johanan fears. Instead, he anguishes over a verse from Jeremiah:

Ask ye now, and see whether a man doth travail with child? Wherefore do I see every man with his hands on his loins, as a woman in travail, and all faces are turned into paleness? Alas! that day is so great there is none like it (Jeremiah 30:6-7).

This is the verse that frightens R. Johanan, for he naturally reads it in his own way. 'Every man' [geber] is not the totality of man; every man designates Him who is virility itself [geburah]. 'Every' is here the adverb 'all'. He who is every man is all man, all humanity,

[25] Levinas, E., Difficult Freedom, John Hopkins University, Baltimore, 1990, pp. 89-90.

[26] Cfr.: García, J. A., Introducción a la filosofía de Levinas, Cuadernos de Anuario Filosófico, Serie universitaria, nº 140, Pamplona, 2001, p. 27.

[27] Levinas, E., Beyond the Verse. Talmudic Readings and Lectures..., p. 64.

[28] Weber, M., «Politicis as a vocation» in Weber's Rationalism and Modern Society, translated and edited by Tony Waters and Dagmar Waters. Palgrave Books 2015, p. 136. 
all virility. At the end of time God holds His hands on His loins, as though in labour. Why does He hold His hands on His loins? Because at the messianic moment He must sacrifice the wicked to the good. Because in the just act there is still a violence that causes suffering. Even when the act is reasonable, when the act is just, it entails violence». ${ }^{29}$

If politics legitimates the use of violence and to inflict suffering, Messianism, on the other hand, means the own power and the own responsibility to bear the suffering of all humankind, and not only for the sufferings of the people of my own present, but also for all the sufferings that the world has ever seen. This seems to be a Christian and not Jewish interpretation of Messianism. As Moyn has shown Levinas has a great debt with Christians scholars, both philosophers like Kierkegaard, writers like Dostoievski and theologians like Barth and Wahl. ${ }^{30}$

\section{Messianism and sacrifice: Levinas on substitution}

Messianism is an attitude of individuals, and not a political legitimation. True messianism does not fight, but it is the attitude to bear the suffering of the other, and to feel my responsibility for any suffering of any human being. This goes beyond any possible calculation of my responsibility, or of any personal responsibility. There are no limits for my accountability. It is obvious that to feel a responsibility for any suffering entails sacrifice as a mode of existence. And sacrifice is what, according to Levinas, makes place for the other:

«the passage of the identical to the other in substitution, which makes possible sacrifice». ${ }^{31}$

I have an unlimited accountability, and as such, an unlimited suffering to shoulder. This seems to be an excessive responsibility. An excess - démesure - of it that can only lead to sacrifice. In chapter V of Otherwise than Being Levinas cites Zosima in Dostoyevsky's Brothers Karama$z o v$ : "each of us is guilty before everyone for everyone, and I more than the others». It seems a huge, radical, and terrible situation that concerns everybody — not only Zosima-, independently of the guilt that appears to his personal consciousness. For that reason, this demand has nothing

[29] Levinas, E., Difficult Freedom, John Hopkins University, Baltimore, 1990, p. 79.

[30] Cf. Moyn, S., Origins of the Other: Emmanuel Levinas between Revelation and Ethics, Cornell University Press, 2005.

[31] Levinas, E., «Substitution», in Emmanuel Levinas: Basic Philosophical Writings, Indiana University Press, Bloomington, 1996, p. 90. 
to do - apparently - with justice. Moreover, if justice has anything to do with reciprocity, Messianism expresses a relationship of non-reciprocity between my responsibility and that of the other. And that means asymmetry in human relationships. ${ }^{32}$ This is the interpretation of Alain Toumayan of Levinas' reception of Dostoyevsky.

However it is possible to offer another reading of the texts. Perhaps there is no asymmetry because all of us have a common guilt, which we must admit. The acknowledgement of it seems to be the confession that "each of us is guilty before everyone», regardless of which crimes everyone has committed, that is: "for everyone». Perhaps every human being is united with the rest of humanity by ties of guilt, or perhaps Zosima is discovering fraternity. Fraternity entails loving links with any other human being, connections which allows us to be ready to sacrifice for the sake of the other, to substitute the guilt of the other.

Cora Diamond gives us a good example of what means fraternity. It is a very fitting example to clarify this mystery of the unlimited guilt.

«The sense of mystery surrounding our lives, the feeling of solidarity in mysterious origin and uncertain fate: this binds us to each other, and the binding meant includes the dead and the unborn, and those who bear on their faces 'a look of blank idiocy', those who lack all power of speech, those behind whose vacant eyes their lurks a 'soul in mute eclipse'». ${ }^{33}$

There is a deep contrast between Zosima's and Ivan Karamazov's visions of justice. For Ivan, justice means lawfulness; and in absence of God, "all is lawful». For Ivan, if there is no God, there is no guilt, only infringement of laws. What a crime is, depends only of the social recognition by law or rules. As Alain Toumayan has argued, Zosima's thesis of my unlimited responsibility, and the infinity of his wish is the counterpoint of Ivan unconstrained arbitrariness.

For Ivan, a right behavior is a recognized and permitted one, as if I would have signed a social contract. This contract is based upon the premise that I exist solely for myself, that I can only accept a loss of freedom for the sake of a profit, like security, etcetera. In consequence, one must respond only to his own actions, and of the suffering he causes. I must pay

[32] Cf:: Toumayan, A., «"I more than the others": Dostoevsky and Levinas» in Yale French Studies, 104 (2004): Encounters with Levinas, p. 55: «the notion of asymmetry or nonreciprocity that it expresses so radically and so strikingly (and that Levinas employs to distinguish his thought from Martin Buber's I/Thou)»

[33] Diamond, C., «The Importance of Being Human» in Cockburn, D., (ed.), Human Beings, Cambridge University Press, Cambridge, 1991, p. 55. 
for my own actions, not for the others. This is for Levinas tantamount to egoism. This is an egotistical calculation of my accountability. However, this egotistical act splits the society, and breaks the human fraternity.

It is true that I can fight for a better world, but that depends upon my personal decision, and just in case my responsibility is not an unlimited one. Freedom for Ivan Karamazov means autonomy, self-reference. Levinas calls this vision of freedom «egotistical». As autonomous being each one must answer exclusively of his autonomous decisions. I can suffer for erroneous or unjust decisions of other persons, and I can choose to fight them. Ivan's sense of justice is then a political one. The egotistical responsibility is only a limited one.

On the contrary, according to Levinas «I approach the infinite by sacrificing myself $» .^{34}$ It is not a coincidence that according to the Bible ${ }^{35}$ the Temple in Jerusalem was built on Mount Moriah, the place of the sacrifice of Isaac. This was the mount of Abraham and Isaac's analempsis (å $v \dot{\alpha} \lambda \eta \mu \psi \iota \varsigma)$, of their ascension to the highest place, to the Infinite. In the Psalms one can find the theme of the ascent to Jerusalem, the pilgrimage of all Nations to the Most High. Because of the sacrifice of Isaac, Abram (which signifies "patriarch») received the name of Ab-raham «father of a multitude ${ }^{36}$. As Maimonides says, Abraham and Isaac sacrifice causes that:

«he (Avraham) is the father of the whole world, who are gathered under the wings of the Shechinah». ${ }^{37}$

This seems to be the symbolic value of the Temple in Jerusalem. By means of sacrificing himself, Abraham is the mystical father of the whole world. And the temple erected in Moriah remembers humanity that sacrifice makes possible the passage from the identical to the other, the fulfilment of the human wish of infinity.

I approach the infinite I wish, by means of sacrifice, that is, by my unlimited answerability. But one can sacrifice himself for... defending a cause, for an ideal, for his parents, for his country, etc. And this form of

[34] Levinas, E., «Enigma and phenomenon» in Emmanuel Levinas: Basic Philosophical Writings..., p. 76.

[35] 2 Chronicles 3:1. «Then Solomon began to build the temple of the LORD in Jerusalem on Mount Moriah, where the LORD had appeared to his father David. It was on the threshing floor of Araunah the Jebusite, the place provided by David.»

[36] Genesis 17:5.

[37] Maimonides, Hilchot Bikurim, c. 4. sect. 3. 
sacrifice entails calculation, and with it, plans, and limits. Perhaps not any form of suffering calls to my responsibility, and my sacrifice can be useless. But for Levinas, a universal responsibility before everyone for everyone involves sacrifice without calculation. Sacrifice transcends utility and identity. However, to the extent that I am "guilty before everyone for everyone, and I more than the others», this sacrifice seems to be not a gratuitous act, because of my guilt. It seems to be a due action.

This seems to be the case of my duties with my fellow men, and not with the whole of humanity. My neighbors - from my parents and friends, to my compatriot - constitute my subjectivity. I am a subjectivity not only because I relate to myself, and because I must become actively myself. It is not sameness that makes me a person, because I am not a separate being. Consequently, the others and my duty with the others are constitutive of my very own being. I am a subjectivity insofar as I respond and answer for the other. I am constituted as subject by the face of the other, and not by my personal autonomy and independence. However, my relationship with the other is an asymmetrical one. He, or she, constitutes me. And for Levinas, the asymmetry broads itself to the whole of mankind. One must care or nurse any other as his brother. Human fraternity is the ground of the unlimited answerability.

«Responsibility does not come from fraternity, it is fraternity that gives responsibility for the other its name, prior to my freedom». ${ }^{38}$

It is not strange that Dostoievski wrote the sentence of Zosima in a book about brothers and fraternity. But how can any other come to my responsibility?

«The way in which the other presents himself, exceeding the idea of the other in me, we here name the face». 39

The face is the mode of appearance for the other that allows to let him to be in its transcendence. Therefore, the face is not the real face of a person which I perceive, but «epiphany and visitation».40 The face is the place of the event in which the transcendence of the other visits and appeals to me. Compared with this event, my own consciousness, my personal ideas about the other, or my identification with him in terms of family, friendship, religion, country etc., are completely irrelevant. The other

[38] Levinas, E., Of God Who Comes to Mind, Stanford University Press, Stanford, 1998, p. 72.

[39] Levinas, E., Totality and Infinity..., op. Cit., p. 50.

[40] Cf.: Toumayan, A., «"I more than the others": Dostoevsky and Levinas»... p. 65. 
transcends my consciousness, my ideas, my interiority, my ideals, and me. Due to its transcendence, the other must not appear to me in anyway, and for this reason, he and me, does not constitute ever a "we». It is not a Hegelian problem of recognition, of identities. I must treat the other always as a guest - without asking his name, without identifying him as...-, I must take care for him. And this taking care is a moral command: Do not kill me! «The ethical responsibility for the other precedes knowledge of the other». ${ }^{41}$ This entails that responsibility is prior to freedom. And that is Zosima's perspective, which involves that our duties are prior to our freedom. For that reason, Zosima's vision of justice is a messianic one.

But why has the other such a power upon myself? Why has it termed Levinas to this vision of justice of «Messianism»? What has all of this got to do with the symbolism of the Temple of Jerusalem?

\section{Fraternity and the rituals performed in the Temple in Je- rusalem}

If Messianism is radically different from politics, then Messianism cannot belong to history, it belongs to another form of temporality, and it belongs to Holy history. And the essence of the Holy History is the "always». By contrast, one can characterize the temporality of the historicism or the political activity as the "never». If time must continue it is for the only reason that the goal and end of history has, until now, never been achieved. I do not want to say that freedom has never been achieved. Of course, it has! "But "never" does not contrast with "sometime" but to "always"». ${ }^{42}$ That is so, because the goal of history must be a universal situation or condition for the whole of humanity. According to Hegel, history needs to spread freedom all over the world. According to Kant, history needs a universal kingdom of ends. "Never» is then, a general notion, and a modal notion, because it has to do with the possibility of history. History is only possible, according to every type of historicism, because its end has never been achieved. This absolute negativity of the end is the motor of time.

But perhaps there are other ways of living in time. Time can be a time of development. But the time of Israel, according to Levinas, the Messianism, is to be subjected to an "always». And that means a time in which any moment could be devaluated. Every moment can have an absolute

[41] Williams, R., Recognition: Fichte and Hegel on the Other, State University of New York Press, New York, 1992, p. 298.

[42] Polo, L., Hegel y el posthegelianismo, Eunsa, Pamplona, p. ¿? 
meaning, and not a relative one. If the time of development is the time of a totality, which spreads itself through every moment, then to attach to a time where there is always a possibility of absoluteness, is to affirm a temporal sequence incapable of constituting a totality. Every moment has an infinite value. No moment is relative to another that confers its meaning. But a moment with infinite value is a moment of holiness, a sacred, blessed and pure moment.

\begin{abstract}
«Does not Israel attach itself to an 'always' - in other words, to a permanence in time, to a time held by moments of holiness, by the way in which they have a meaning or are 'so close to the goal' - and where not one of these moments is lost, or to be lost, but they are all to be deepened, that is to say, sublimated? And instead of remaining word, a purely theoretical view or doctrinal affirmation, or some sort of coexistence of moments of time passing, do not this predilection and this signification of the always call for a whole structuring of concrete human reality and a whole orientation of social and intellectual life - perhaps justice itself - which would render only such a signification possible and significant? ». ${ }^{43}$
\end{abstract}

Levinas «believes that revelation is an event that places each of us in a certain position, posture or attitude prior to anything that we do or any act we perform». ${ }^{44}$ But according to Levinas, revelation occurs in the face-to-face relationship, not in symbols. It is the face of any other person that calls me to be concerned for him. One can see in the face of the other the divine command to accept him, to accept his humanity, and to respond to him. Then, we can ask ourselves if there can be a revelation in stones, instead of the human face? Does not that mean a contradiction in a central theme of Levinas' philosophy?

As a ruin, the Temple of Jerusalem is not only a fragment of a magnificent political past of the Jewish People. As a dead thing, as a ruin, it speaks about the eschatology. And it speaks, to humankind, but making each human being free from the concern of a time to come, and absolving him from the worry about future and history, which founds politics.

«The eschatological, as the 'beyond' of history, draws beings out of the jurisdiction of history and the future; it arouses them in and calls them forth to their full responsibility. It restores to each instant its full signification in that very instant». ${ }^{45}$

[43] Levinas, E., Beyond the Verse..., op. cit., p. 17.

[44] Morgan, M., Discovering Levinas, Cambridge University Press, Cambridge MA, 2007, p. 214.

[45] Levinas, E., Totality and Infinity, Duquesne University Press, Pittsburgh, 1969, p. 23. 
Levinas speaks about the meaning of the eschatological as always, and not as something beyond time, when he comments another Talmudic text. This is the Tractate Menahoth 99b-100a, which speaks of the Mish$n a$, one of the most sacred rituals performed at the Temple in Jerusalem. The Mishná is the ceremony in which the priests every Sabbath leaves bread on a golden table before the Lord, and eats the bread, which they put on the table seven days before. Levinas emphasizes the permanence of the ritual:

«The position of the bread on the table, continually before the Lord - 'before me [continually]', says the text. It is the meaning of permanence». ${ }^{46}$

To emphasize permanence means to underscore eternalness, perpetuity. The ritual is a perpetual duty. Not only a duty performed only on Sabbath, because there was fresh bread always, permanently there, on the tables. And that speaks about a permanent present, about every instant, not about future. Levinas ask himself:

«What does permanence signify? What does the 'always' signify? How can the always have signification? How does Israel think the significance of the always? ${ }^{47}$

The Bread on the table has the name of Shewbread: the bread that shows, the bread of faces ${ }^{48}$. According to Levinas, politics in Israel has a different meaning from that of western's historicism. Political activity, and the ideal of a politician in Israel, has a perfect symbol in the figure of Joseph in the book of Genesis. "Kingship in Israel is always Joseph feeding the people». ${ }^{49}$ The king must nurture his people. A king is the one who argues against Cain's statement: "Yes, you are the nurse of your fellow men». And this feeding of the hungry is performed and symbolized at the core of the Temple of Jerusalem. The kingship of somebody relates to the sacred action of compassion, an action before the face of the other. And an action, which must always be performed at the core of the Temple. The priests enter in the Sancta Sanctorum looking in every moment at their faces, puts the new bread on a gold table, and comes from this room with the bread of the last Sabbath looking mutually to the faces, and eating them after depositing it on another gold table. These priests perform the ritual of the always, the ritual of the Mishná, by which «the permanence

[46] Levinas, E., Beyond the Verse..., op. Cit., p. 16.

[47] Ibid., p. 17.

[48] Ibid., p. 18.

[49] Ibidem. 
of the human is ensured by the solidarity constituted around a communal work». ${ }^{50}$

The Temple of Jerusalem symbolizes then, the «always». It symbolizes that the moment of absolute value, are all the moments during which we feed and take care of the others. For that reason, the symbol of the Temple of Jerusalem is, at the same time, a symbol of the most sacred, because it «is an exact replica of the heavenly Temple, the order of absolute holiness». ${ }^{51}$ So, we have that the Temple in Jerusalem represents in Earth the Heavenly Temple. It is exactly an imago Templi, and an imago of eternity, and of justice.

But if the Temple was destroyed, and only its ruins remain forever, the rituals performed by the People of Israel constitute the face to face relationship that can always save the world and judge it. Perhaps the most known of these rituals is the twice a day pray of the Shema Ysra'el. "According to the rabbinical tradition, this prayer expresses the acceptance of the 'celestial yoke', the submission to the Law. Submission to the Law, permanence of service». ${ }^{52}$ Service must be performed always. And for that reason, before everyone. Each son of Abraham must care for «before everyone and for everyone». We have just remembered this sentence of the staret Zosima, his testament, that must be accepted always (twice a day) by the Jewish People, it is an acceptance of the "celestial yoke» for everyone before everyone.

[50] Ibid., p. 23.

[51] Levinas, E., Beyond the Verse..., op. Cit., p. 158.

[52] Ibid., p. 25. 